\title{
Bioethics and the Myth of Neutrality
}

\author{
Angus Dawson - Christopher F. C. Jordens • \\ Paul Macneill • Deborah Zion
}

Published online: 28 November 2018

(C) Journal of Bioethical Inquiry Pty Ltd. 2018

Keywords Bioethics · Neutrality · Advocacy $\cdot$ Asylum seekers $\cdot$ Human rights $\cdot$ Bioethics organizations

Thou shalt not be a victim, thou shalt not be a perpetrator, but above all, thou shalt not be a bystander. - Yehuda Bauer

Bioethics is concerned with ethical issues relating to health and the life-sciences (Potter 1971). It has become an academic discipline over the last fifty yearsalthough the subject-matter, methods, and focus of the discipline remain disputed (Dawson 2010). Given this lack of consensus, it might be argued that bioethics organizations ought to be neutral in the sense that they should not adopt particular substantive positions on contested issues and that their primary duty is to foster the widest possible discussion and debate. After all, reasonable people can disagree (for example) about the permissibility of abortion and euthanasia, or how to allocate scare resources, or whether animals should ever be used in medical experimentation. In such cases we can and should focus on the quality of the relevant

A. Dawson $(\bowtie) \cdot$ C. F. C. Jordens · P. Macneill

Sydney Health Ethics, Faculty of Medicine and Health, Level 1, Medical Foundation Building, K25, University of Sydney,

Sydney, NSW 2006, Australia

e-mail: angus.dawson@sydney.edu.au

D. Zion

Human Research Ethics Committee, Victoria University, Footscray Park Campus, Victoria 3011, Australia analysis and argumentation, or dispute the appropriateness or quality of relevant evidence, or argue about the plausibility and force of premises in arguments. But does it follow that neutrality is an appropriate stance where sustained harm is deliberately inflicted on vulnerable populations or where there are clear failures to abide by international human rights norms? To remain silent and fail to act to end abuse by appealing to "neutrality" in such circumstances is a dereliction of responsibility and an acquiescence to continuing abuse.

Take as an example the treatment of asylum seekers. Migration is a feature of our modern world that raises many ethical issues (Wild and Dawson 2018). Some people relocate by choice but many do not. Those who seek asylum are the most vulnerable - forced to move as a consequence of violence (or threat of violence) due to political, religious, or ethnic conflicts. They often flee with nothing but their lives, having suffered torture, rape, and dispossession. A raft of international agreements since the Second World War provide a series of binding obligations upon states to protect such people, provide necessities such as shelter and healthcare, and speedily process claims to refugee status. However, across the world, many countries contravene their obligations. Asylum seekers are increasingly excluded from care by countries barricading their borders. At this moment, children are separated from parents in North America. Syrian families fleeing civil war are turned away from the borders of European countries. Ethnic groups, most notably the Rohingya, are forced out of their homeland. Can, and should, we be "neutral" about such issues? 
Australia was one of the first countries to sign the 1951 Refugee Convention, which "recognizes the right of persons to seek asylum from persecution in other countries." Between 1948 and 2010, almost 700,000 refugees were settled in Australia (about 10 per cent of Australia's migrant intake). In 1992 however, the Australian government introduced a system of mandatory administrative detention for asylum seekers while their claims for refugee status are assessed. For many years those seeking asylum were held in onshore detention centres like Woomera and Baxter, where conditions often impacted negatively on detainees' health. Nonetheless, onshore detention meant that human rights organizations had some access to detention centres. However, in 2001, the Coalition government instituted the practice of offshore detention. It was dismantled by the Labor Rudd government in 2008 but reinstituted by the Labor Prime Minister Julia Gillard in 2012. It has been supported by both major political parties ever since (Dehm and Walden 2018). Detention of those who have attempted to come to Australia by boat continues on Manus Island (in Papua New Guinea) and Nauru.

The Australian government has been criticized by the United Nations on a number of occasions (Melzer 2018) and also by peak human rights bodies within Australia (Australian Human Rights Commission 2017). The government has nevertheless failed to address the pressing health needs of those detained, both those arising from trauma and persecution before entering the camps and those arising from abuse in the camps themselves. Health treatment is basic at best with examples of detainees dying from simple infections and as a result of mental health issues (McCall 2017). Processing of claims for refugee status is deliberately slow and even once attained does not end in transfer to Australia. Rather than address these issues, the Australian government has tried to silence clinicians, criminalize advocacy, and exclude journalists from the camps. Notably, the Border Force Act (2015), which was passed with bipartisan support, made it unlawful for healthcare professionals to disclose anything they came to know as a result of working inside the system of immigration detention, with a penalty of up to two years imprisonment. This has created an ethical minefield for healthcare professionals working within the system, and this clearly marks the issue as being of central relevance to bioethics (Briskman and Zion 2014; Essex 2016).
Many healthcare professionals have spoken out and challenged the government to prosecute them (Sanggaran et al. 2015), and peak bodies of health professionals have made clear their objections to the government's harsh and inhumane policies and called for action. These include the Australian Medical Association $(2011,2015)$, the Public Health Association of Australia (on behalf of no less than fourteen peak health care bodies) (2015); the Royal Australasian College of Physicians (Paxton, Cherian, and Zwi 2015), and the Australian Psychological Society (2011). Recent opinion polls and political events in Australia such as the Wentworth by-election suggest that public opinion is moving against the unrelenting persecution of detainees, particularly children (The Guardian Australia 2018). Amidst the mounting dissent, we should ask ourselves: "Where should the bioethics community stand?"

The Australasian Bioethics Association (ABA) condemned the treatment of refugees as early as 2002 by issuing a public statement and writing to the then Prime Minister and Minister of Immigration (McNeill 2003). However the succeeding body, the Australasian Association of Bioethics and Health Law (AABHL) the (now) peak body in the region - has remained silent on this issue. It is constrained by a "neutrality" policy by which it "does not formulate or support particular policy positions on any ... issues." 1 What could justify the neutrality of bioethics bodies in the face of policies that deliberately harm some of the most vulnerable in our global community and put healthcare professionals in impossible moral binds?

There are a number of possible reasons for inaction grounded in a claim of the need for "neutrality" that might be given, but they are not very convincing. First, it might be held, as suggested above, that this is an issue where reasonable people within the field of bioethics can disagree. To this we would reply that there are no reasonable bioethical or legal arguments for failing to respect the human rights of asylum seekers or failing to offer adequate medical treatment and social services without which individuals might die or continue to suffer. Furthermore, Australia has deliberately used cruel treatment of refugees in its off-shore detentions centres as a deterrent to others who may seek to come to

\footnotetext{
${ }^{1}$ In 2009, the Australasian Bioethics Association and the Australian Institute of Health, Law and Ethics, merged to become the Australasian Association of Bioethics and Health Law (AABHL). Its "neutrality" policy is to be found at: http://aabhl.org/ See "About us"/"Policies."
} 
Australia by boat (The Guardian Australia 2017). No humane society can justify such a policy, especially when it thereby fails to meet its international human rights obligations. Second, perhaps it might be argued that this is a political issue and therefore lies outside of the remit of a bioethics organization. To this we would respond that whilst the exact boundary of any distinction between politics and ethics is unclear, both lie within the domain of bioethics at least in relation to some issues. Even if one seeks to remain focused only on ethics, there are clear grounds for action. Key relevant concepts such as vulnerability, compassion, beneficence, and nonmaleficence are all central to ethical discussion.

The positive arguments for action by bioethical organizations in such a case of neglect, abuse, and cruelty are overwhelming (McNeill 2003). As bioethicists we have an individual responsibility to act, and we have responsibilities as part of a community, to act together on behalf of others in urgent need, especially where they cannot act in their own interests and/or are silenced by authorities. We, with others, have argued that AABHL also has a responsibility to speak out and act. At a recent conference in Townsville, together with other members of the organization, we drafted a declaration to add AABHL's voice to other professional organizations that condemn the harms inflicted by current policies and call on the Australian government to pursue a rights-based and humane approach to people seeking asylum. Despite some opposition the Townsville Declaration was put to a vote of the membership of AABHL to ensure that the organization as a whole could be seen to stand together and support the need for action. We are pleased to report it was passed by the overwhelming majority of those who voted. ${ }^{2}$

There is currently a resurgence of interest in and debate on the role of bioethicists as advocates. We welcome this. However, it is also important that we discuss the appropriate role and responsibilities of bioethical associations. And we must accept the responsibilities that attach to silence and inaction. Bioethics has always aimed to be practical, to make a difference to practice and policy, particularly when standing with those who are marginalised. Such actions are necessarily political. We call on the bioethics community to examine critically the myth of neutrality in bioethics.

\footnotetext{
$\overline{2}$ The AABHL "Townsville Declaration" can be found here: http://aabhl.org/app/articles/articles/view/aabhl-2018-conferencestatement. Accessed November 3, 2018.
}

\section{References}

Australian Human Rights Commission. 2017. Asylum seekers, refugees and human rights. Snapshot Report, 2nd ed. Sydney: AHRC. https://www.humanrights.gov.au/ourwork/asylum-seekers-and-refugees/publications/asylumseekers-refugees-and-human-rights-snapsho-0. Accessed October 29, 2018.

Australian Medical Association. 2011, 2015. Health care of asylum seekers and refugees. https://ama.com.au/positionstatement/health-care-asylum-seekers-and-refugees-2011revised-2015. Accessed October 29, 2018.

Australian Psychological Society. 2011. Psychological wellbeing of asylum seekers and refugees in Australia: A position Statement. https://www.psychology.org.au/About-Us/Whatwe-do/advocacy/Position-Statements/Psychologicalwellbeing-refugees-and-asylum-seeker. Accessed October 29, 2018.

Briskman, L., and D. Zion. 2014. Dual loyalties and impossible dilemmas: Health care in immigration detention. Public Health Ethics 7(3): 277-286.

Dawson, A. 2010. The future of bioethics: Three dogmas and a cup of hemlock. Bioethics 24(5): 218-225.

Dehm, S., and M. Walden. 2018. Refugee policy: A cruel bipartisanship. In Double disillusion: The 2016 Australian Federal Election, A. Gauja, P. Chen, J. Curtin, and J. Pietsch, eds, 593-617. Canberra: Australian National University Press.

Essex, R. 2016. Healthcare and clinical ethics in Australian offshore immigration detention. The International Journal of Human Rights 20(7): 1039-1053.

The Guardian Australia. 2017. UN official says Australia responsible for "inhuman" treatment of asylum seekers. June 12. https://www.theguardian.com/australia-news/2017/jun/12 /un-official-says-australia-responsible-for-inhumantreatment-of-asylum-seekers. Accessed October 29, 2018.

- 2018. Kerryn Phelps urges Wentworth voters to use byelection to protest "inhumane" refugee policies. October 14. https://www.theguardian.com/australia-news/2018 /oct/14/kerryn-phelps-urges-wentworth-voters-to-usebyelection-to-protest-inhumane-refugee-policies. Accessed October 29, 2018.

McCall, C. 2017. Urgent medical attention needed for people on Nauru. The Lancet 389(10157): 1507-1508.

McNeill, P. 2003. Public health ethics: Asylum seekers and the case for political action. Bioethics 17(5/6): 487-502.

Melzer, N. 2018. Report of the Special Rapporteur on torture and other cruel, inhuman or degrading treatment or punishment. Human Rights Council. A/HRC/37/50. https://www.ohchr. org/Documents/Issues/Torture/A HRC 3750 EN.pdf. Accessed October 29, 2018.

Paxton, G.A., S. Cherian, and K. Zwi. 2015. The Royal Australasian College of Physicians position statement on refugee and asylum seeker health. Medical Journal of Australia 203(4): 176-177.

Potter, V.A. 1971. Bioethics: Bridge to the future. Englewood Cliff, NJ: Prentice-Hall.

Public Health Association of Australia. 2015. Media release 18 March 2015. Coalition of peak health bodies calls for release of children from immigration detention. 
http://journalists.medianet.com.au/DisplayAttachment. asp $\mathrm{x} \cdot \mathrm{j}=824186 \& \mathrm{~s}=2 \& \mathrm{k}=3118986$. Accessed October 29, 2018.

Sanggaran, J-P., R. Kidd, G. Ferguson, B. Hew, A. Bleaney, M. Williams, et al. 2015. Open letter on the Border Force Act: "We challenge the department to prosecute." The Guardian
Australia, July 1. https://www.theguardian.com/australianews/2015/jul/01/open-letter-on-the-border-force-act-wechallenge-the-department-to-prosecute. Accessed October 29 , 2018.

Wild, V., and A. Dawson. 2018. Migration: A core public health ethics issue. Public Health 158: 66-70. 